\title{
Identifikasi Nilai Pedagogis Tarian Lulo untuk Memperkuat Rasa Persatuan pada Anak Usia Dini
}

\author{
Nasir', Rahmawati M², Adam ${ }^{3}$ \\ Administrasi Pendidikan, Universitas Muhammadiyah Kendari ${ }^{12}$ \\ Prodi Pendidikan Anak Usia Dini, Universitas Muhammadiyah Kendari ${ }^{3}$ \\ DOI: $\underline{10.31004 / \text { obsesi.v4i1.336 }}$
}

\begin{abstract}
Abstrak
Penelitian ini mengidentifikasi nilai pedagogis tarian Lulo guna memperkuat karakter persatuan pada anak usia dini. Penelitian dilatarbelakangi oleh berita tentang banyaknya tindakan-tindakan kekerasan dan bullying di kalangan siswa, di mana anak-anak menjadi aktornya. Oleh karena itu, dibutuhkan sebuah nilai yang bisa menguatkan rasa kasih dan persatuan. Melalui pendekatan ethnography, peneliti melibatkan beberapa pihak sebagai sumber informasi, seperti: tokoh masyarakat, ahli kurikulum, administrator sekolah; kepala sekolah dan guru-guru (partisipan FGD). Dokumentasi dari observasi langsung untuk memberikan visual serta mengkonfirmasi data-data dari wawancara. Analisa data dilakukan sesuai prosedur analisa interkatif, analisa domain dan taksonomi Spradley. Peneliti menyimpulkan jika tarian lulo memenuhi prinsip-prinsip kurikulum untuk menjadi media dan atau input pembelajaran di pendidikan anak usia dini, karena tarian lulo berisi unsur kegiatan pikir, olah hati, olah rasa, karsa, serta olah raga dan mengandung nilai-nilai positif. Internalisasi tarian Lulo dalam kurikulum pendidikan membekali anak didik dengan nilainilai yang mengajarkan rasa persatuan, saling menghargai, cinta perdamaian, toleransi dan patuh terhadap aturan mutlak diperlukan.
\end{abstract}

Kata Kunci: kurikulum pendidian anak usia dini; tarian lulo; tradisi local; tolaki.

\begin{abstract}
This study identifies the pedagogical value of the Lulo dance in order to strengthen the character of unity in early childhood. The research is motivated by news about the many acts of violence and bullying among students, where children are the actors. Therefore, we need a value that can strengthen love and unity. Through the ethnography approach, researchers involve several parties as a source of information, such as: community leaders, curriculum experts, school administrators; the principal and teachers (FGD participants). Documentation from direct observation employed to provide visuals and confirm data from interviews. Data analysis was performed according to interactive analysis procedures, domain analysis and Spradley's taxonomy. Researchers concluded that lulo dance meets curriculum principles to become a medium and / or learning input in early childhood education, because lulo dance contains elements of thought activity, heart processing, exercise feeling, intention, and sports and contain positive values. Internalization of the Lulo dance in the educational curriculum equips students with values that teach a sense of unity, mutual respect, love of peace, tolerance and obedience to the rules absolutely necessary.
\end{abstract}

Keywords : early childhood curriculum; local wisdom; lulo dance, tolaki.

Copyright (c) 2019 Nasir, Rahmawati M, Adam

$\triangle$ Corresponding author:

Email Address : dhion_zir@yahoo.com (Kendari, Sulawesi Tenggara)

Received 22 November 2019, Accepted 6 December 2019, Published 9 December 2019

Jurnal Obsesi : Jurnal Pendidikan Anak Usia Dini, 4(1), 2020 | 359 


\section{PENDAHULUAN}

Sebagai bangsa yang masyarakat dan budayanya sangat beragam, Indonesia terdiri dari ragam pulau, bahasa, agama, suku, ras dan lain-lain (Syam, 2011). Dalam kemajemukan itu, seharusnya masyarakat Indonesia tetap memiliki satu tujuan dan harus mampu hidup dengan rukun. Namun kenyataanya, pluralitas masyarakat tidak dapat mendamaikan perbedaan yang terjadi. Sikap individualisme muncul sebagai sikap dominan. Setiap orang merasa apa yang dianut atau yang dipercaya adalah yang paling benar, sedangkan milik orang lain adalah salah. Sebagai warga Indonesia yang menganut asas "Bhineka Tunggal Ika" sebaiknya masyarakat tidak mendiskriminasi sesama (orang yang memilki faham berbeda). Pada konteks persekolahan, anak didik harus bisa mengenal mana yang benar, dan sangat memedulikan tentang yang benar, dan melakukan apa yang mereka yakini sebagai yang benar walaupun ada tekanan dari luar dan godaan dari dalam (Raharjo, 2010).

Perilaku individualism dan pluralisme diakibatkan oleh berkurangnya penyelenggaraan pendidikan karakter di sekolah-sekolah (Tatman, Robert, Stacey Edmonson, 2009). Sejauh ini, prularitas masyarakat lebih banyak menghasilkan dampak negatif dibandingkan dampak positifnya. Dampak negatif terjadi karena sebagian pihak mengklaim yang paling benar dan orang lain yang 'berbeda' dianggap salah. Dampak negatif pluralitas yang terjadi di Indonesia dengan indikasi seperti: penghancuran tempattempat ibadah, rasisme dan permasalahan politik. Sementara itu, pluralisme pula berpotensi menimbulkan perpecahan oleh beberapa kalangan; timbulnya persaingan, adanya kekerasan karena kurangnya rasa toleransi, munculnya rasisme, egoisme, dan timbulnya perilaku individualisme. Padahal, keberagaman juga mebawa dampak positif seperti dijadikan sebagai kekayaan negara, membentuk masyarakat yang modern, meningkatkan peningkatan pendapatan negara, dan menjadi daya tarik bagi turis untuk datang ke Indonesia. Selain itu, pluraslisme juga akan melatih kita untuk saling menghormati, saling menghargai, membuktikan kepada dunia bahwa Indonesia merupakan negara yang kaya akan perbedaan namun tetap damai dan juga memotivasi untuk anak-anak generasi selanjutnya untuk memelihara kesatuan bangsa.

Dalam rangka meningkatkan nilai-nilai toleransi di tengah keanekaragaman, pendidikan adalah garda depan terciptanya rasa toleransi. Pendidikan menurut UU SISDIKNAS No. 20 Tahun 2003 adalah usaha sadar dan terencana untuk mewujudkan suasana belajar dan proses pembelajaran agar peserta didik secara aktif mengembangkan potensi dirinya untuk memiliki kekuatan spritual keagamaan, pengendalian diri, kepribadian, kecerdasan, akhlaq mulia serta memiliki keterampilan yang diperlukan dirinya dan masyarakat. Pendidikan harus ditempatkan pada garda depan dalam metode konstruksi teologi pluralisme dengan membuat metodologi yang tepat untuk mendukungnya. Konstruksi pendidikan masa lalu yang berbasiskan penyeragaman identitas budaya bangsa, harus dikaji ulang dan perlu disesuaikan dengan paradigma pendidikan yang berbasis pluralisme bangsa. Paradigma pendidikan yang tidak berbasis pluralisme dapat terlihat lewat distorsi yang muncul kepermukaan.

Dalam banyak penelitian, mengintegrasikan budaya dalam proses pembelajaran akan membawa beberapa manfaat, karena sejatinya sekolah merupakan tempat integrasi budaya, sekolah memungkinkan siswa untuk membentuk hubungan dengan diri sendiri, orang lain dan lingkungan sekitar (Lareau \& Weininger, 2003). Ini juga memberi pengetahuan dan pemahaman kepada generasi muda tentang warisan budaya dan pencapaian manusia di zaman dahulu (Folarin \& Olanrewaju, 2014). Mengintegrasikan budaya sebagai bagian dari pendidikan akan memungkinkan siswa untuk: mempersiapkan mereka lebih efektif untuk menghadapi berbagai situasi dalam kehidupan, menempatkan mereka dalam lingkungan fisik dan sosial dengan lebih baik, dan menjadikan mereka terlibat dalam masyarakat dengan semangat pengakuan atas keunikan dan toleransi atas keragaman manusia dan budaya. Menggali dan melestarikan kearifan lokal atau tradisi dapat berfungsi secara efektif dalam pendidikan karakter (Fajarini, 2014). Obanya menegaskan jika budaya dan 
DOI: 10.31004/obsesi.v4i1.336

pendidikan tidak dapat dipisahkan, karena keduanya bagaikan dua sisi mata uang (Obanya, 2005). Konsep budaya dan pendidikan sebenarnya tidak dapat dibedakan, karena definisi utama dari pendidikan adalah "akulturasi". Bahkan budaya lokal masih merupakan bagian penting dari kehidupan sosial di era globalisasi (Pekajová, Lívia \& Novosák, 2010), karena budaya bersifat dinamis dalam merespon perubahan dan tekanan modernitas (J, George \& Die, 2011).

Merujuk pada berita IDN Times tanggal 12 April 2019 yang telah merangkum kasus bullying dan kekerasan yang terjadi di lingkungan pendidikan bahwa kekerasankekerasan tersebut dilakukan oleh teman siswa mereka sendiri. Bahkan tulisan Kang Warsa yang dimuat dalam kompasiana.com menyebutkan tindak kekerasan anak (mengeroyok, menendang, dan memukuli siswa perempuan) di Kota Bukit Tinggi dilakukan oleh anakanak SD. Perilaku kekerasan sesama anak menunjukkan belum tumbuhnya rasa solidaritas, kasih sayang dan kebersamaan (Andina, 2014). Seharusnya penanaman karakter persatuan pada siswa dimulai sejak masa emas yaitu pendidikan dasar dan usia dini. Menghubungkan penelitian-penelitian terdahulu pada paragraph sebelumnya dengan fakta-fakta yang dipaparkan di atas, kearifan lokal merupakan modal dasar yang yang dapat digunakan untuk menumbuhkan karakter persatuan dan kesatuan anak (Nasir, 2013). Dalam penelitiannya tentang budaya lokal di Sulawesi Tenggara Kota Kendari, Nasir menyebutkan jika tari Lulo mampu mengasah, melatih, menjaga fisik, pengetahuan, sikap dan keterampilan para siswa. Merujuk pada Konfigurasi Pendidikan Karakter, pendidikan adalah keseluruhan dari olah pikir, olah hati, olah raga, dan olah rasa atau karsa (Kementrian Pendidikan Nasional, 2011). Dengan demikian, tulisan ini akan menganalisa kandungan pedagogis tari lulo untuk integrasi masyarakat sebagai konsukuensi pluralitas Negara Indonesia.

\section{METODE PENELITIAN}

Penelitian ini berbasis pada penelitian kualitatif dengan pendekatan ethnograpy, karena kegiatan di dalam penelitian ini mengkaji kehidupan suatu kelompok atau masyarakat secara ilmiah yang bertujuan untuk mempelajari, mendeskripsikan, menganalisia, dan menafsirkan pola budaya suatu kelompok tersebut dalam hal perilaku, kepercayaan, bahasa, dan pandangan yang dianut bersama (Cresswell, 2012). Melalui pendekatan pendekatan ethnograpy diharapkan dapat teridentifikasi kandungan pedagogis tarian lulo. Di samping itu, analisa domain dan taknosonomi Spradley juga dilakukan untuk menelaah makna filosofi tarian lulo.

Dalam proses pengumpulan data, tim peneliti melakukan wawancara kepada 2 (dua) tokoh masyarakat, 1 (satu) ahli kurikulum dan juga melakukan Focus Group Discussion (FGD) bersama guru-guru di sekolah lingkup Dinas Pendidikan Kota Kendari. Selain itu, beberapa hasil observasi (foto-foto) dihadirkan untuk memberikan visual (gambaran) untuk mendukung data-data dari wawancara. Untuk menganalisa data-data yang diperoleh, peneliti penggunakan analisa domain dan analisa taksonomi Spradley. Peneliti juga melakukan triangulasi sumber dan teknik pengumpulan untuk menjamin validitas data yang diperoleh. Di samping itu, peneliti merujuk dari penelitian-penelitian terdahulu untuk memahami fenomena-fenomena yang dttemui dan mengkofirmasi fakta-fakta yang diperoleh di lapangan.

\section{HASIL PENELITIAN}

\section{Makna Tarian Lulo}

Tari lulo atau molulo merupakan salah satu tarian tradisional masyarakat Kendari khususnya masyarakat Suku Tolaki. Meskipun demikian, tari lulo telah banyak dimainkan oleh suku lain yang ada di Sulawesi Tenggara bahkan di provinsi lain di Indonesia. Tari lulo sebenarnya adalah tarian yang sangat merakyat dan dikenal hampir seluruh lapisan masyarakat. Karena tarian lulo adalah tari pergaulan, maka lulo bersifat terbuka termasuk 
segala kemungkinan perubahan dan inovasi atas tarian ini. Seorang tokoh masyarakat memberikan penjelasan mengenai tatakrama dan etika dalam menarikan tarian Lulo. Sebagai sebuah budaya, tari lulo berfungsi sebagai identitas, pengikat, kekuatan penggerak atau pengubah, pembentuk nilai tambah, pola perilaku, warisan dan lain-lain. Berdasarkan penjelasan seorang Tokoh Adat Masyarakat Tolaki diketahui jika filosofi tarian lulo adalah persahabatan dan mempererat tali persaudaraan. Tarian lulo dilakukan dengan posisi saling bergandengan tangan dan membentuk sebuah lingkaran. Maknanya mencerminkan bahwa masyarakat Suku Tolaki sangat mencintai kedamaian dan menomorsatukan persahabatan dan persatuan dalam bingkai kehidupan nusantara. Disebutkan sebelumnya jika melakukan tarian lulo yaitu dengan posisi tangan saling bergandengan dan pesertanya membentuk sebuah lingkaran. Posisi tersebut sebagaimana terlihat pada gambar di bawah ini:

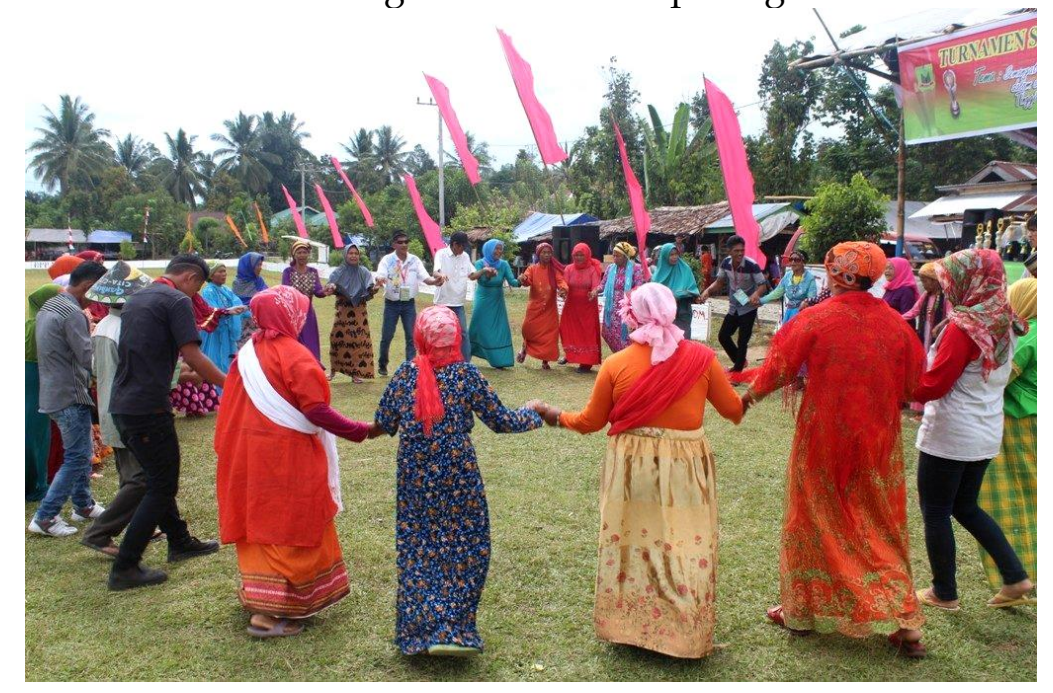

Gambar 1 Bentuk Lingkaran dan Posisi Tangan Peserta Tarian Lulo

Gambar di atas memperlihatkan posisi tangan yang sudah saling mengait, selanjutnya ditambahkan dengan gerakan turun naik bersama dengan pasangan untuk mengimbangi gerakan kaki yang maju mundur, kekiri dan kekanan sesuai tempo irama musik pengiring. Para penari berputar membentuk lingkaran. Lelaki, perempuan, tua, muda, yang bekerja ataupun penggangguran saling mengenggam tangan, melebur bergerak seirama menjadi satu. Tidak ada yang marah jika salah dalam gerakan, melainkan terus mencoba dan membenarkan langkah hingga akhirnya bisa sama dengan yang lainnya.

Peserta tari lulo tidak dibatasi oleh usia maupun golongan, siapa saja boleh turut serta dalam tarian lulo; kaya miskin, tua, muda boleh bahkan jika anda bukan suku Tolaki atau dari daerah/negara lain bisa bergabung dalam tarian lulo, yang penting adalah bisa mengikuti gerakan tarian ini. Hal lain yang perlu diperhatikan karena posisi tangan saat bergandengan tangan, untuk pria posisi telapak tangan di bawah menopang tangan wanita. Posisi tangan ini merupakan simbolisasi dari kedudukan, peran, etika pria dan wanita dalam kehidupan. Keterangan berkaitan dengan etika molulo dijelaskan oleh seorang partisipan dalam kegiatan FGD. Sebagaimana tertulis pada petikan di bawah ini:

"Seseorang tidak boleh masuk diantara kedua penari tanpa izin. Demikian pula untuk memutuskan genggaman dari penari lainnya memerlukan izin atau pemberitahuan. Jika seseorang masuk dalam genggaman, dan pihak lain tidak suka pada orang tersebut maka ia tidak bisa langsung memutuskan (keluar), tapi harus bersabar dengan terus bermain kurang lebih satu putaran. Aturan tersebut harus ditaati untuk menghindari konflik dan ketersinggungan antara satu dengan yang lainnya, sebab itu sudah diatur dalam etika tarian Lulo..." (PrtspnFGD) 
DOI: 10.31004/obsesi.v4i1.336

Keterangan dari partisipan FGD di atas, selanjutnya peneliti konfirmasi kepada Ketua Forum Masyarakat Tolaki. Sebagai tokoh ada masyarakat tolaki, beliau menjelaskan etika molulo secara lebih detail. Penjelasan tersebut sebagaimana dalam petikan di bawah ini:

“... Lulo memiliki nilai-nilai humanisme. Molulo (menari lulo) bisa dijadikan sebagai tarian keakraban, bisa menjalin kembali tali persaudaraan yang mulai jauh. Di samping itu juga merupakan tempat untuk mencari jodoh sebagai awal perkenalan. Yang paling penting menyehatkan dan menghilangkan stress" (TM)

"Sebenarnya, tarian ini memiliki tatakrama sebelum masuk arena tarian. Misalkan ketika akan masuk, harus dari depan. Ketika ada wanita berpengangan dengan pria, kita tidak boleh langsung masuk diantara pengangan itu, tetapi mencari wanita yang berpengangan dengan wanita. Maka barulah kita bisa masuk di tengah untuk mengenggan tangan wanita yang satu kiri dan wanita yang satu tangan kanan pula, laki-laki berada di tengah. Kalau mengambil posisi diantara pria dan wanita, maka sama saja kita menantang pria itu, seakan-akan kita akan mengambil pasangannya" (TM)

“.. cara masuk memang harus dari depan, aturannya tidak diperbolehkan masuk dari belakang. Bila laki-laki akan molulo, lantas wanita menolak, bisa di kenakan denda adat (entah apa denda itu aku lupa). Tapi sebaliknya, bila ketika ada wanita mau molulo dengan pria, namun pria itu enggan lantas meninggalkan arena, maka wanita yang mau molulo bisa mengadu ke tetua adat. Maka akan didenda dengan seekor kerbau tambah dua lembar sarung (Toloa)" (TM)

Keterangan di atas mengisyaratkan bahwa kehidupan ini mempunyai aturan yang wajib dipatuhi. Aturan-aturan tersebut mengatur seluruh aspek kehidupan sehingga siapapun yang mematuhinya akan "selamat". Sedangkan berkaitan dengan seragam yang digunakan para penari, seorang partisipan FGD lainnya juga berkomentar tentang kostum tarian lulo. Komentar tersebut sebagaimana tertuang dalam petikan di bawah ini:

"Untuk kostum yang digunakan para menari, secara orisinisil biasanya disesuaikan dengan acara. Ketika lulo dilakukan pada acara adat biasanya menggunakan busana adat Suku Tolaki. Demikian pula jika tarian lulo dipentaskan dalam pertunjukan tari atau festival budaya, juga menggunakan busana adat. Sedangkan untuk upacara di luar adat biasanya bisa dilakukan dengan seragam bebas rapi..." (PrtspnFGD)

Busana adat Suku Tolaki yang disebutkan pada petikan di atas, sebagaimana terlihat dalam gambar di bawah ini:

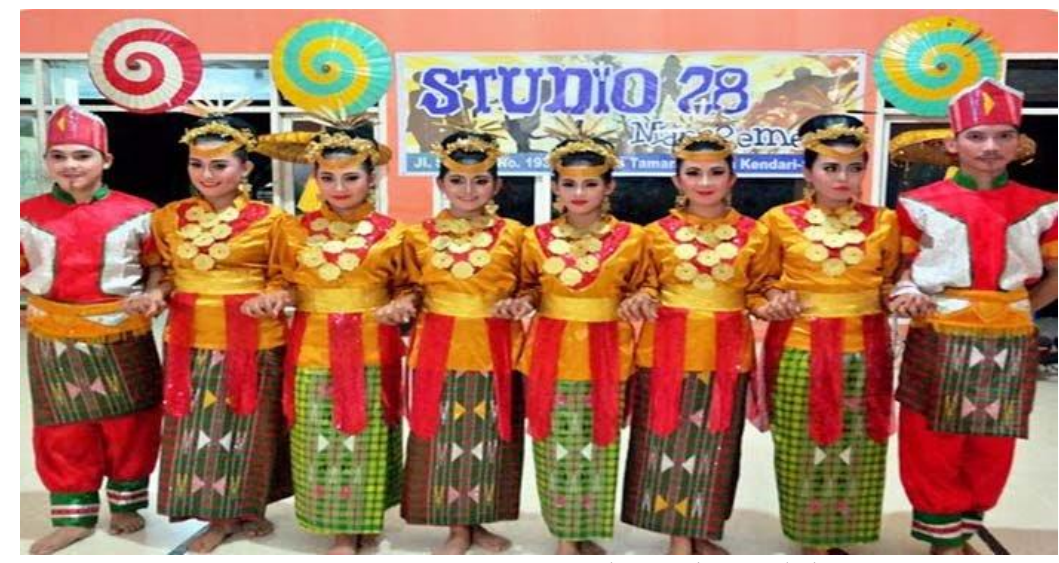

Gambar 2

Baju Adat Suku Tolaki

(Dokumentasi Sanggar Studio 28 Kota kendari) 
Pada aspek musik pengiring, tarian lulo biasanya diiringi dengan musik dangdut, elekton. Pada zaman dahulu, tarian lulo diiringi dengan suara gong yang ditabuh dengan ritme teratur dan indah. Dengan masuknya alat pengiring elektronik baik berupa kaset dan speaker besar serta elekton, terjadilah pergeseran fundamental terhadap jenis gerakan dan irama tarian lulo.

Tarian Lulo mencerminkan bahwa masyarakat Tolaki adalah masyarakat yang cinta damai dan mengutamakan persahabatan dan persatuan dalam menjalani kehidupannya. Seperti filosofi masyarakat Tolaki yang diungkapkan dalam bentuk pepatah samaturu, medulu ronga mepokoaso, yang berarti masyarakat Tolaki dalam menjalani perannya masingmasing selalu bersatu, bekerja sama, saling tolong-menolong dan bantu-membantu. Sebagai sebuah kebudayaan, lulo merupakan jati diri masyarakat Tolaki; ciri dan merupakan suatu keistimewaan. Oleh karena itu penting untuk menjaga nilai kebudayaan serta menjaga kelestariannya.

\section{Karakteristik Materi Pembelajaran}

Berkenaan dengan sub ini, peneliti banyak berdiskusi dengan pakar di bidang kurikulum. Harapannya, kepakaran dari ahli tersebut akan memberikan gambaran yang lebih komperehensif berkaitan dengan aspek-aspek yang layak menjadi input dalam pendidikan. Selain itu, keterangan-keterangan yang relevan juga digali dari guru dan kepala sekolah. Beberapa contoh pertanyaan utama yang peneliti ajukan kepada para informan seperti: Bagaimana karakteristik input (materi) pembelajaran? Tanggapan mereka tentang budaya sebagai materi pembelajaran, dan bagaimana internalisasinya dalam kurikulum pendidikan di sekolah? Pertama, peneliti bertanya tentang apa itu materi pembelajaran. Jawaban-jawaban informan tertuang dalam petikan-petikan di bawah ini:

"Materi Pembelajaran sebenarnya merupakan bagian tidak bisa dipisahkan dengan Silabus, yakni perencanaan, prediksi dan proyeksi tentang apa yang akan dilakukan pada saat kegiatan pembelajaran..." (Gr)

"Secara garis besar dapat dibilang bahwa materi pembelajaran adalah pengetahuan, keterampilan, dan sikap yang harus dikuasai peserta didik dalam rangka memenuhi standar kompetensi yang ditetapkan.

"Sebenarnya materi pembelajaran adalah sebuah pengetahuan, keterampilan dan juga sebuah sikap yang harusnya dimiliki oleh semua peserta didik di dalam memenuhi standar pembelajaran kompetensi yang telah di tetapkan" (Gr)

"Pada umumnya sebuah materi pembelajaran ini telah di bagi menjadi tiga jenis yakni alat, informasi dan juga sebuah teks atau program yang di perlukan oleh para guru untuk melakukan sebuah perencanaan belajar. Sebuah alat yang dipergunakan oleh guru untuk menerapkan sebuah pembelajaran yang baik dan mudah di mengerti para siswanya" (Gr)

Memahami arti materi pelajaran ini sangat penting untuk dapat di mengerti oleh semua siswa supaya setiap siswa dapat menerima pembelajaran sesuai dengan yang telah di tetapkan oleh guru. Maka dari itu dapat di simpulkan bahwa sebuah materi pelajaran ini sangat berpengaruh pada tingkat keberhasilan ataupun ketercapaian siswa di dalam belajar. Adapun karakteristik yang harus dipenuhi oleh materi pembelajaran sebagaimana hasil wawancara di bawah ini:

“Input atau materi pembelajaran harus mampu membawa dampak positif dan perubahan tingkah laku dalam diri siswa. Perubahan tingkah laku tersebut meliputi perubahan kognitif (pengetahuan), afektif (sikap) dan psikomotor (keterampilan).." (Exprt) 
Selain memperhatikan jenis materi juga harus diperhatikan prinsip-prinsip yang perlu digunakan dalam menentukan cakupan materi pembelajaran yang menyangkut keluasan dan kedalaman materinya. Dinyatakan oleh informan bahwa:

"Keluasan cakupan materi berarti menggambarkan seberapa banyak materi-materi yang dimasukkan ke dalam suatu materi pembelajaran. Kedalaman materi menyangkut rincian konsep-konsep yang terkandung di dalamnya yang harus dipelajari oleh peserta $\operatorname{didik}($ Exprt)

Tanggapan informan tentang budaya sebagai materi pembelajaran, dan bagaimana internalisasinya dalam kurikulum pendidikan di sekolah sebagaiamana penjelasanpenjelasan berikut ini:

"Budaya tidak terintegrasi dengan bidang ilmu lain. Proses belajar tentang budaya, sudah cukup dikenal selama ini, misalnya mata pelajaran kesenian dan kerajinan tangan, seni dan sastra, seni suara, melukis atau menggambar, seni musik, seni drama, tari dan lain-lain. Budaya dipelajari dalam satu mata pelajaran khusus, tentang budaya. Mata pelajaran tersebut tidak terintegrasi dengan mata pelajaran lain, dan tidak berhubungan satu sama lain" (Exprt)

"Pembelajaran budaya dilandaskan pada pengakuan terhadap budaya sebagai bagian yang fundamental bagi pendidikan. Pembelajaran budaya dapat dibedakan menjadi empat macam, yaitu belajar tentang budaya, belajar dengan budaya, belajar melalui budaya, dan belajar berbudaya" (Kepsek)

Pandangan ahli di atas bisa disimpulkan bahwa memisahkan pendidikan dari kebudayaan merupakan suatu kebijakan yang merusak perkembangan kebudayaan sendiri, malahan mengkhianati keberadaan proses pendidikan sebagai proses pembudayaan. Nilainilai budaya yang menjadi roh pendidikan merupakan nilai luhur yang telah hidup di msyarakat. Dalam budaya terdapat pesan hidup, pesan moral sehingga tercipta masyarakat yang berkarakter.

\section{Analisa Domain dan Taksonomi}

Sebagaimana tujuan penelitian ini yaitu untuk mengidentifikasi kandungan pedagogis Tarian Lulo. Oleh karena itu, analisa domain dan analisa taksonomi dilakukan pada data-data yang kumpulkan dari FGD dan wawancara terbuka sebagaimana terlihat pada gambar di bawah ini:

Tabel 1 Analisis Domain Penelitian

\begin{tabular}{|c|c|c|}
\hline Rincian Domain & $\begin{array}{l}\text { Hubungan } \\
\text { Semantik }\end{array}$ & Domain \\
\hline Lulo biasa & \multirow{3}{*}{ Jenis } & \multirow{3}{*}{ Tarian lulo } \\
\hline Lulo patah-patah & & \\
\hline Lulo kreasi & & \\
\hline $\begin{array}{l}\text { Mata pelajaran } \\
\text { Ekstra-kurikulum }\end{array}$ & Ruang & Kurikulum \\
\hline $\begin{array}{l}\text { Musik elektronik } \\
\text { Intervensi budaya asing }\end{array}$ & \multirow[t]{2}{*}{ Sebab akibat } & \multirow[t]{2}{*}{$\begin{array}{l}\text { Pakem dan kesakralan lulo } \\
\text { berubah }\end{array}$} \\
\hline $\begin{array}{l}\text { Tidak suka perdamaian } \\
\text { Individualistik }\end{array}$ & & \\
\hline Tidak sopan & \multirow{4}{*}{$\begin{array}{l}\text { Rasional atau } \\
\text { alasan }\end{array}$} & \multirow{4}{*}{$\begin{array}{l}\text { Integrasi Lulo dalam kurikulum } \\
\text { sekolah }\end{array}$} \\
\hline Tidak tertib & & \\
\hline Sombong & & \\
\hline Semena-mena & & \\
\hline
\end{tabular}




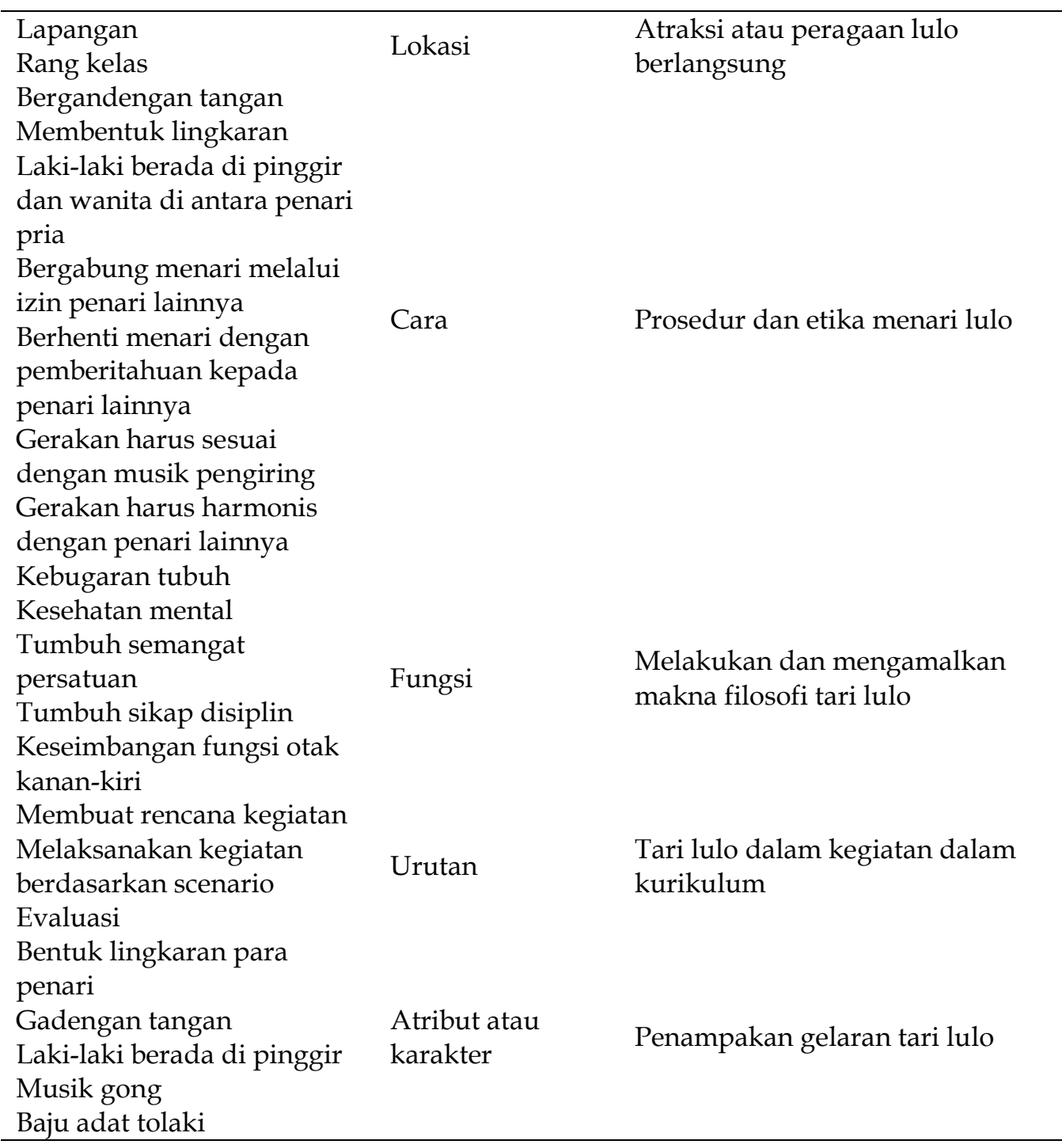

Sebagaimana analisa domain di atas, melakukan dan mengamalkan makna filosofi tarian Lulo dipilih penulis sebagai cover term (domain terpilh) untuk dijabarkan lebih jauh dan dipahami lebih mendalam dalam analisa taksonomi. Kedua analisa tersebut dilakukan untuk mengetahui makna-makna; gerakan, bentuk, busana yang digunakan, tata cara pelaksanaan hingga musik pengiring tarian lulo. Selanjutnya makna-makna yang telah diketahui, diindentifitasi variabel pedagogis yang terkandung didalamnya melalui diskusi bersama dengan beberapa pakar pendidikan. Peneliti juga mengobservasi secara langsung pelaksanaan tarian lulo pada beberapa kesempatan. Gambar-gambar berikut ini adalah alur analisa taksonomi: 

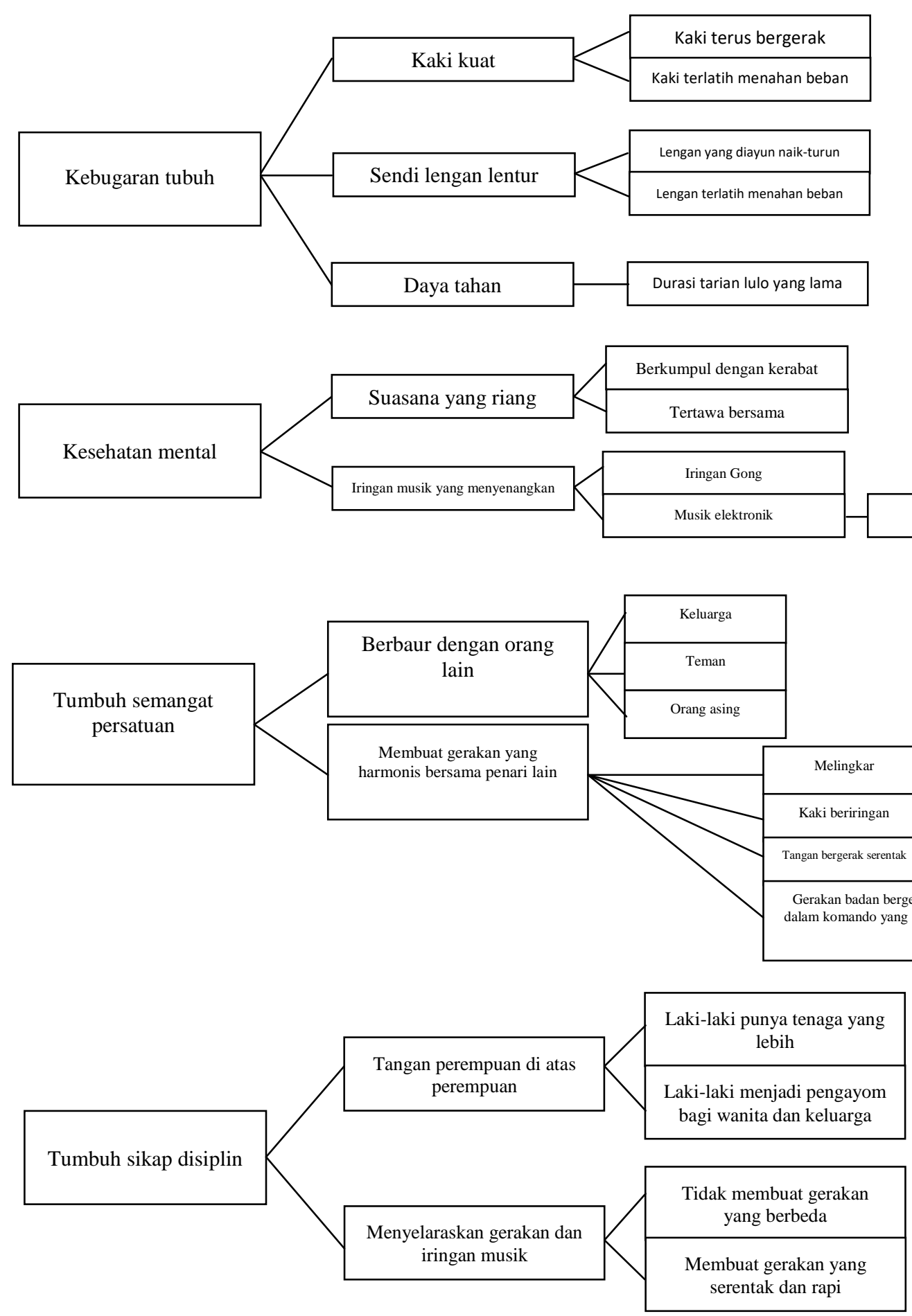

Gambar 3 Analisa Taksonomi (makna filosofi tarian Lulo sebagai cover term)

\section{PEMBAHASAN}

Tujuan dari penelitian ini yaitu melakukan pengakajian terhadap kandungan pedagogis tarian lulo agar bisa diadaptasi sebagai media dan sarana untuk menumbuhkan karakter rasa persatuan pada pendidikan anak di usia dini. Tarian Lulo dianalisa dari sisi gerakannya, prosedur pelaksanaan, kostum, musik pengiring hingga nilai filosofi yang ada dalam tarian tersebut. Apakah memenuhi kelayakan untuk dijadikan sebagai media dan atau sarana pebelajaran pendidikan bagi anak di usia dini! 
Pembelajaran merupakan strategi penciptaan lingkungan belajar dan perancangan pengalaman belajar yang juga mengintegrasikan budaya sebagai bagian dari proses pembelajaran (Hanum, 2009); Dirjen Dikti, 2004). Belajar dengan budaya dapat menjadikan siswa tidak terasing dari budaya lokalnya serta meningkatkan apresiasi siswa terhadap budaya lokal. Pembelajaran berabasis budaya juga merupakan pembelajaran yang bersifat konstruktivistik (Alexon, 2010). Bahkan Juanda meyebutkan bahwa pendidikan karakter dalam fable sebagai bagian dari budaya lokal dapat diterapkan pada pembentukan karakter anak usia dini dengan pengasuhan sejak usia dini (sejak bayi) dan pendidikan dini anakanak (Juanda, 2019). Dekimian pula kesimpulan Fauziddin \& Mufarizuddin mengatakan jika permainan tradisional seperti Clap Hand bisa mengoptimalkan aspek perkembangan aspek koginitf anak (Fauziddin \& Mufarizuddin, 2018).

Merujuk Tramonte \& Willms (Caprara, 2016), dalam pembelajaran berbasis budaya, budaya menjadi sebuah metode bagi siswa untuk mentransformasikan nilai-nilai di dalamnya menjadi aspek yang membentuk karakter (personality). Melalui pembelajaran berbasis budaya, siswa bukan sekadar meniru dan atau menerima informasi yang disampaikan, tetapi siswa menciptakan makna, pemahaman,dan arti dari informasi yang diperolehnya karena pengetahuan bukan sekadar rangkuman naratif dari pengetahuan yang dimiliki orang lain, tetapi suatu koleksi (repertoire) yang dimiliki seseorang tentang pemikiran, perilaku, keterkaitan, prediksi dan perasaan, hasil transformasi dari beragam informasi yang diterimanya.

Pembelajaran berbasis budaya merupakan salah satu cara yang dipersepsikan dapat menjadikan pembelajaran bermakna dan kontekstual, dan menjadikan pembelajaran menarik dan menyenangkan. Di samping itu, model pengintegrasian budaya dalam pembelajaran dapat memperkaya budaya lokal (etnis), akhhirnya akan mampu mengembangkan dan mengukuhkan budaya lokal berkembang.

Analisa tim peneliti menemukan jika tarian Lulo berisi kegiatan fisik yang terlihat dari gerakan tangan yang saling bergandengan diikuti dengan gerakan tangan naik turun, semua kaki penari bergerak ke kiri dan ke kanan sesuai aturan dan alunan musik. Di samping itu, pelibatan rasa dan karsa juga terlihat ketika gerakan-gerakannya harus digerakkan sesuai irama musik pengiring, membuat tampilan yang indah, menarik dan memunculkan sukacita serta semangat. Masing-masing penari bergerak bersama-sama dalam gerakan yang sama dan seirama dengan musik. Oleh karena itu, tarian lulo bisa disimpulkan sebagai kegiatan fisik, rasa dan karsa (Al Ashur, 1997). Meskipun demikian, untuk memenuhi standar media dan atau sarana pebelajaran pendidikan bagi anak di usia dini tarian Lulo harus memenuhi setidaknya unsur grafis, audio, permainan dan simulasi (Chukwbikem, 2013).

Unsur grafis pada prinsipnya semua jenis media dalam yang digunakan untuk menyampaikan pesan lewat simbol-simbol visual dan melibatkan rangsangan indera penglihatan. Sebagaimana terlihat dalam aspek atribut dan karakter analisa domain, pelibatan indera mata untuk memainkan tarian lulo mutlak diperlukan. Bentuk lingkaran para penari harus terus dipertahankan sampai tarian selesai. Tangan penari laki-laki pun harus selalu berada di bawah gandengan tangan penari wanita. Kesesuaian gerak semua penari, harus terjaga (tampak sama dan seirama). Adapun unsur audio yaitu hakekat dari jenis-jenis media berupa pesan yang disampaikan atau dituangkan ke dalam simbol-simbol auditif (verbal dan/atau non-verbal), yang melibatkan rangsangan indera pendengaran. Selain gerakan-gerakan dinamis, tarian lulo juga melibatkan suara (musik) sebagai pengiring. Musik tersebut bisa berupa bunyi-bunyi alat musik (gong), vokal berirama, dan atau penggabungan keduanya; alat musik dan vokal (life dan rekaman). Sedangkan unsur permainan dan simulasi adalah ciri atau karakteristik dari media yang melibatkan anak didik secara aktif dalam proses belajar, interaksi antar anak didik, dan dapat memberikan umpan balik langsung. Dalam gelaran tarian lulo, para penari harus memainkan peranannya masing. Penari laki-laki berada di ujung barisan (penjaga), sedangkan penari-penari wanita berada di tengah garis barisan sebagaimana bisa dilihat pada gambar 2. Prosedur-prosedur 368 | Jurnal Obsesi : Jurnal Pendidikan Anak Usia Dini, 4(1), 2020 
dan aturan-aturan tersebut merupakan simbol yang mempunyai makna dan nilai-nilai humanism untuk memupuk keakraban, menjalin kembali tali persaudaraan dan mempererat pesatuan.

Berdasarkan narasi di atas, bisa dikatakan jika tarian lulo memenuhi untuk menjadi media dan atau sarana pebelajaran pendidikan bagi anak di usia dini karena memenuhi unsur grafis, audio, permainan dan simulasi atau dalam terminologi umum disebut dengan kegiatan pikir, olah hati, olah rasa dan karsa, serta olah raga yang mengandung nilai, kemampuan, kapasitas moral dan ketegaran dalam menghadapi kesulitan dan tantangan (Lapasoro, 2014). Olah pikir dalam artian proses nalar guna mencari dan menggunakan pengetahuan secara kritis, kreatif, dan inovatif menhasilkan pribadi cerdas (kognitif). Olah hati meliputi perasaan sikap dan keyakinan/keimanan yang menghasilkan pribadi jujur (afektif). Olah rasa dan karsa yaitu kemauan yang tercermin dalam kepedulian. Sedangkan olah raga adalah proses persepsi, kesiapan, peniruan, manipulasi dan penciptaan aktivitas baru yang disertai dengan sportivitas menghasilkan pribadi yang tangguh. Sebagaimana dikatakan Nasir $d k k$, bahwa tari lulo yang wujudnya berupa gerakan serentak, berirama dan teratur mampu mengasah/melatih/menjaga fisik, pengetahuan, sikap dan keterampilan para siswa (Nasir, Mujiati, \& Asrul, 2019).

Melihat rumusan pendidikan Stella Van Petten Henderson bahwa pendidikan adalah kombinasi pertumbuhan, perkembangan diri dan warisan sosial (Jæger, 2011). Sedangkan Ki Hadjar Dewantara mengatakan bahwa usaha-usaha pendidikan ditujukan pada membentuk halusnya budi, cerdasnya otak dan sehatnya badan (Mulyasa, 2002). Ketiga usaha itu akan menjadikan lengkap dan selaras bagi manusia. Pendidikan juga harus melatih seseorang untuk berpikir cepat, tegas dan efektif. Pendidikan harus memungkinkan seseorang menjadi lebih efisien, untuk mencapai tujuan dalam hidupnya. Pendidikan harus memungkinkan pria menjadi lebih efisien, untuk mencapai dengan meningkatkan fasilitas tujuan yang sah dalam hidupnya.

Narasi-narasi di atas mengilustrasikan sebuah alur kesimpulan penelitian sebagaimana tertuang pada gambar di bawah ini:

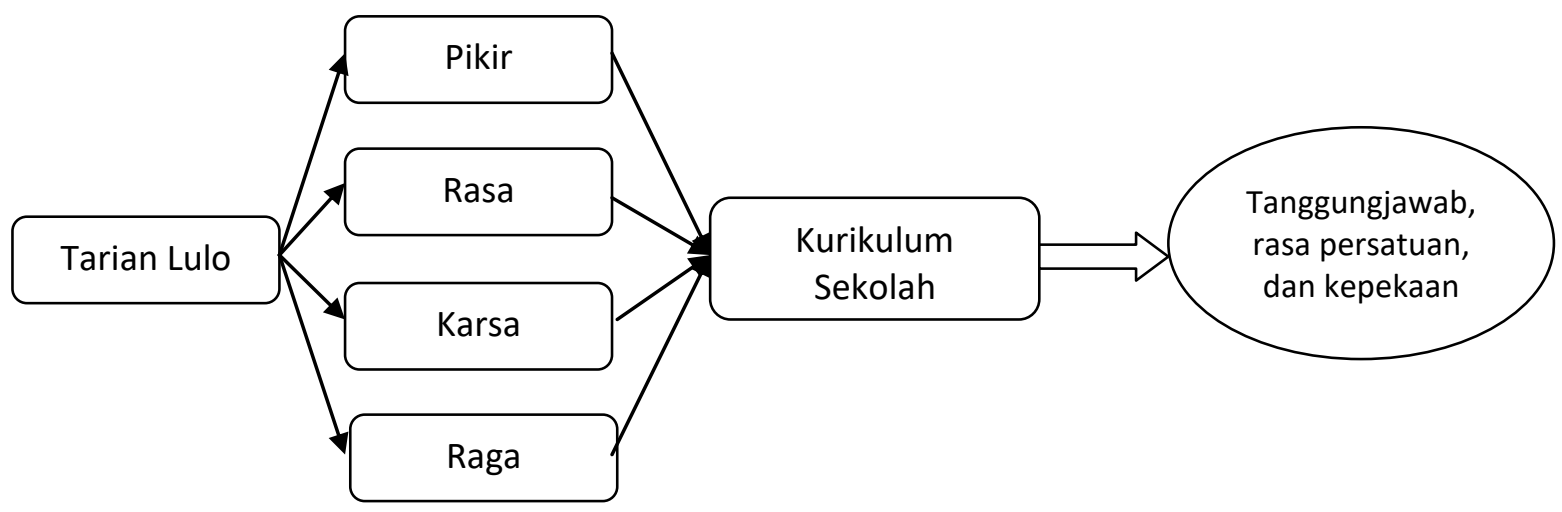

Gambar 4 Alur Kesimpulan Penelitian

Pertanyaan selanjutnya, apa dan bagaimana menerapkan tarian lulo sebagai bagian kurikulum Pendidikan Anak Usia Dini? Kurikulum Pendidikan Anak Usia Dini atau Acuan Menu Pembelajaran Pendidikan Anak Usia Dini (Menu Pembelajaran Generik) merupakan rangkaian rencana dan pengaturan kegiatan pengembangan dan pendidikan yang dirancang sebagai panduan dalam menyelenggarakan kegiatan pendidikan anak usia dini (Istiana, 2014). Kerangka pendidikan anak usia dini dikembangkan untuk mendorong para pendidik dan penyedia layanan, administrator, dan pembuat kebijakan untuk memasukkan pembelajaran awal termasuk permainan, baik tradisional maupum modern (Perkins dan Taylor, 2016). 
Mengingat unsur-unsur yang dikandungnya, tarian lulo sebagai media dan sarana pembelajaran dapat dimasukkan sebagai salah satu aktivitas bermain bagi anak yang akan menjadi bekal dan pondasi tumbuhnya perilaku sosial anak, dan melatih pengendalian diri yang merupakan suatu prasyarat untuk berperilaku baik dan positif di masa yang akan datang. Internalisasi tarian lulo dalam kurikulum juga sebagai wujud pemeliharaan budaya agar terus eksis. Peneliti menegaskan bahwasannya tarian lulo sebenarnya adalah tarian yang sangat merakyat karena dalam pergelarannya bisa diikuti oleh siapapun; tua-muda, kaya-miskin, hingga orang asing pun boleh bergabung. Tarian tradisi yang merupakan warisan nenek moyang suku Tolaki merupakan sebuah kesenian yang melibatkan struktur gerak, perasaan, dan juga membutuhkan keterampilan para penarinya. Berdasarkan struktur geraknya, makna dari gandengan tangan para penari berarti simbol persatuan yang harus ada dalam kehidupan bermasyarakat, sebagaimana pribahasa yang mengatakan "bersatu kita kuat, bercerai kita runtuh". Sedangkan bentuk lingkaran yang ditunjukkan para penari merupakan simbol dari sebuah siklus kehidupan yang mengisyaratkan seperti roda yang berputar. Simbol tersebut mengharapkan agar manusia tidak memandang rendah atau sombong kepada siapapun, karena akan datang masa ketika kesuksesan berubah menjadi kesusahan. Sedangkan struktur perasaan dilihat dari keserasian musik pengiring dan gerakan para penari. Penari harus bergerak secara serentak dan bersama-sama; tindakan membuat gerakan yang berbeda dengan penari lainnya. Dalam kehidupan bermasyarakat, dibutuhkan keserasian sosial. Setiap warga harus tunduk pada aturan-aturan yang sudah ditetapkan.

Merujuk pada banyak konsep yang dirumuskan para ahli, konsep pendidikan merupakan proses yang melibatkan stimulasi pertumbuhkan jasmani dan rohani agar peserta didik bisa menjadi pribadi yang sehat, cerdas, berperilaku baik dan terampil. Oleh karena itu, peneliti menyimpulkan jika tarian lulo memenuhi untuk menjadi input atau materi pembelajaran di pendidikan anak usia dini bahkan hingga pendidikan tinggi karena memenuhi unsur kegiatan pikir, olah hati, olah rasa dan karsa, serta olah raga yang mengandung nilai-nilai positif; persatuan, sikap menghargai dan tunduk pada norma atau aturan.

\section{SIMPULAN}

Penelitian ini menyimpulkan jika tarian lulo mengandung makna-makna positif yang mengajarkan rasa persatuan, sikap saling menghargai, mencintai perdamaian, toleransi dan patuh terhadap aturan. Dengan adanya berbagai kasus kekerasan dan bulyying yang terjadi di kalangan para siswa, pendidikan (persekolahan) perlu membekali anak didik dengan nilai-nilai dasar dengan cara menanamkan semangat persatuan melalui nilai yang telah menjadi bagian dari tradisi atau budaya masyarakat atau komunitas tertentu dalam kurikulum pendidikan. Penanaman semangat persatuan tersebut bisa dimulai sejak masa emas (golden age) anak yaitu pendidikan dasar dan usia dini. Peneliti juga merokemendasikan kepada pihak yang berwenang (pengelola pendidikan, tenaga pegajar, masyarakat dan pemerintah) di Pronvisi Sulawesi Tenggara agar menetapkan tarian lulo sebagai bagian dari kurikulum yang wajib ada pada kurikulum sekolah, khususnya sekolahsekolah di Kota Kendari mulai dari level pendidikan taman kanak-kanak, sekolah dasar, pendidikan menengah hingga sekolah menengah atas. Di samping itu, kebijakan tersebut akan memelihara dan melestarikan budaya sebagai warisan yang berharga.

\section{UCAPAN TERIMAKASIH} terima

Tulisan ini tersusun atas pasritisipasi banyak pihak, untuk itu penulis mengucapkan kasih kepada orang-orang yang turut berkontribusi di antaranya: Rektor Universitas Muhammadiyah Kendari (UMK) yang telah memberikan rekomendasinya, DIKTI dengan hibah dananya, teman-teman dosen di lingkup FKIP UMK untuk motivasinya, serta semua 
DOI: 10.31004/obsesi.v4i1.336

informan (Tokoh Masyarakat, unsur Kepala Dinas Pendidikan Sulawesi Tenggara, kepala sekolah, guru-guru dan lain-lain), serta para partisipan FGD. Ucapan terima kasih juga peneliti berikan kepada TIM editor Jurnal Obsesi (Jurnal Pendidikan Anak Usia Dini, Universitas Pahlawan) yang telah memberikan saran, masukan, dan pelayanan untuk kesempurnaan artikel ini.

\section{DAFTAR PUSTAKA}

Al Ashur, A. (1997). Tokoh dan Adat Budaya Tolaki. In Erlangga. Kendari.

Alexon. (2010). Pembelajaran terpadu berbasis budaya. Bengkulu: Unit FKIP UNIB Press.

Andina, E. Budaya Kekerasan Antar Anak di Sekolah Dasar. , VI Kajian Singkat terhadap Isu-Isu Terkini (2014).

Caprara, B. (2016). The Impact of Cultural Capital on Secondary Student's Performance in Brazil. Universal Journal of Educational Research, 4(11), 2627-2635. https://doi.org/10.13189/ujer.2016.041116

Chukwbikem, P. E. I. (2013). Resources for Early Childhood Education (E.C.E). Mediterranean Journal of Social Sciences, 4(8), 161-172. https:// doi.org/10.5901/mjss.2013.v4n8p161

Cresswell, J. W. (2012). Eduactional Research: Planning, Conducting, and Evaluating Quantitative and Qualitative Research. In $\square \square \square \square \square \square$. New Jersey: Person Education, Inc.

Fajarini, U. (2014). Peranan Kearifan Lokal Dalam Pendidikan Karakter : Vol. 1, No. 2. Sosio Didaktika, 1(2). https:/ / doi.org/10.15408/sd.v1i2.1225.

Fauziddin, M., \& Mufarizuddin, M. (2018). Useful of Clap Hand Games for Optimalize Cogtivite Aspects in Early Childhood Education. Jurnal Obsesi : Jurnal Pendidikan Anak Usia Dini, 2(2), 162. https://doi.org/10.31004/obsesi.v2i2.76

Folarin, S. F., \& Olanrewaju, I. P. (2014). Cultural Plurality, National Integration and the Security Dilemma in Nigeria. Covenant University Journal of Politics and International Affairs, 2(1), 81-92.

Hanum, F. Pendidikan Multikultural sebagai Sarana Pembentuk Karakter Bangsa (Dalam Perspektif Sosiologi Pendidikan). In Makalah disampaikan pada Seminar Regional DIY-Jateng dan sekitarnya yang diselenggarakan Himpunan Mahasiswa Pendidikan Sosiologi Universitas Nege. , (2009).

Istiana, Y. (2014). Konsep-Konsep Dasar Pendidikan Anak Usia Dini. Didaktika, 5(1), 329-333. https:// doi.org/10.1101/112268

J, George \& Die, S. (2011). Integrating Local Cultural Knowledge as Formaland Informal Education for Young African Learners: A Ghanaian Case Study. Canadian and International Education/Education Canadienneet International, 40(1), 48-56.

Jæger, M. M. (2011). Does Cultural Capital Really Affect Academic Achievement? New Evidence from Combined Sibling and Panel Data. Sociology of Education, 84(4), 281298. https:// doi.org/10.1177/0038040711417010

Juanda, J. (2019). Pendidikan Karakter Anak Usia Dini melalui Sastra Klasik Fabel Versi Daring. Jurnal Obsesi : Jurnal Pendidikan Anak Usia Dini, 3(1), 39. https://doi.org/10.31004/obsesi.v3i1.126

Kementrian Pendidikan Nasional. (2011). Panduan Pengembangan dan Pendidikan Budaya dan Karakter Bangsa: Pedoman Sekolah. Jakarta: Badan Penelitian dan Pengembangan Pusat Kurikulum.

Lapasoro, A. (2014). Kajian Semantik Tuturan Mombesara pada Pelaksanaan Upacara Adat Suku Tolaki. Kendari: Universitas Haluoleo.

Lareau, A., \& Weininger, E. B. (2003). Cultural Capital in Educational Research: A Critical Assessment. Theory and Society, 32(5/6). https://doi.org/10.1023/B:RYSO.0000004951.04408.b0.

Mulyasa, E. (2002). Kurikulum Berbasis Kompetensi. In Depdiknas. Bandung: Bandung: Remaja Rosdakarya. 
Nasir, N. (2013). Pengembangan Pendidikan Karakter Berbasis Budaya Lokal. Universitas Muhammadiyah Surakarta.

Nasir, N., Mujiati, M., \& Asrul, A. (2019). SAMATURU: Menstimulasi Spirit Kolaborasi Guru untuk Melaksanakan Lesson Study. Edum Journal, 2(2), 120-132. https:// doi.org/10.31943/edumjournal.v2i2.49

Obanya, P. (2005). Culture-In-Education and Education-In-Culture. Fifth Conference of African Ministers of Culture 10-14 December 2005 Nairobi, Kenya. Culture-InEducation and Education-In-Culture. Fifth Conference of African Ministers of Culture 10-14 December 2005 Nairobi, Kenya, 7(3), 133-145. https:/ / doi.org/10.17265/2159

Pekajová, Lívia \& Novosák, J. (2010). The goals of education. Local Culture in the Era of Globalisation: Focused on the Zlin Region. In Beyond Globalisation: Exploring the Limits of Globalisation in the Regional Context (Conference Proceedings), 169-176. Ostrava: University Oity of Ostrava Czech Republic, 2010., 88(4), 264-272.

Perkins, E. A., \& Taylor, P. D. (2009). Learning Through Play. Journal of the Institute of Mental Subnormality (APEX), 4(1), 34-34. https:/ / doi.org/10.1111/j.1468-3156.1976.tb00222.x

Raharjo, S. B. (2010). Pendidikan Karakter Sebagai Upaya Menciptakan Akhlak Mulia. Jurnal Pendidikan Dan Kebudayaan, 16(3), 229-238. https://doi.org/10.24832/jpnk.v16i3.456.

Syam, F. (2011). Dilema Pluralitas: Hambatan Atau Penguatan Demokrasi Bangsa Indonesia? Jurnal Ilmu Hukum, 11(2), 10-14. https://doi.org/10.16194/j.cnki.311059/g4.2011.07.016

Tatman, Robert, Stacey Edmonson, J. R. S. (2009). Character Education: An Historical Overview. National Council of Professors of Educational Administration, 4(1). 